\title{
ZNACZENIE INNOWACJI TECHNOLOGICZNYCH DLA BEZPIECZEŃSTWA PODMIOTÓW PAŃSTWOWYCH W CZASIE GLOBALNEGO ZAGROŻENIA BEZPIECZEŃSTWA SANITARNEGO - WYBRANE ASPEKTY
}

\section{The importance of technological innovations for the security of state entities in the time of global threats to sanitary safety - selected aspects}

\begin{abstract}
Abstrakt: Badawczym celem artykutu byto zweryfikowanie hipotezy, zgodnie z która innowacje technologiczne przyczyniaja się do systemowego bezpieczeństwa w okresie pandemii COVID-19. Obszar analizy obją kluczowe zestawienia dotyczace dostępnych danych na temat impulsów innowacyjności w pierwszym okresie pandemii (2020 - okres wiosenno-jesienny). W świetle danych potwierdzono wiodacy trend wykorzystania zaawansowanych technologii bazujacych na cyfrowym zapisie w promowanych rozwiazaniach. Innowacyjność doby pandemii spetnia warunki nie tyle klasycznych definicji pojęcia innowacji, co ujęć typu ultra-fast-innovation, stanowiących twórcze wykorzystanie narzędzi zdigitalizowanych. Innowacje technologiczne spetniaja swoja funkcje wpierania procesu bezpieczeństwa w warunkach, w których zakłada się, że sieciowe systemy przechowywania i wymiany danych działaja niezawodnie i sa odporne na systemowe kryzysy, co stanowi potencjalne systemowe zagrożenie.
\end{abstract}

Słowa kluczowe: bezpieczeństwo, system państwowy, systemy bezpieczeństwa, innowacyjność, pandemia, bezpieczeństwo zdrowotne, nowe technologie

Abstract: Research goal of the article has been set to verify the hypothesis according to which technological innovations contribute to systemic safety during the COVID-19 pandemic. The analyzed area contains key statements of available data regarding innovation impulses in the first pandemic period (2020 - spring/autumn). In the light of this data new trend has been confirmed to be using advanced technologies based on digital records in promoted solutions. Innovation in pandemic days meets conditions, not by classic definitions of the term "innovation" but rather "ultra-fast-innovation" which creatively uses

1 Dr Anna Makuch, adiunkt, Wydział Politologii, Akademia Ekonomiczno-Humanistyczna w Warszawie, e-mail: a.makuch@vizja.pl, ORCID: 0000-0002-5222-4407 
digitalized tools. Technological innovations fulfill their role of aiding the safety process under the conditions which assume that network-based storage and data transfer systems are reliable and resistant against systemic crisis, which is a potential systemic threat.

Keywords: security, state system, security systems, innovation, pandemic, health security, new technologies

\section{Wstęp}

Badawczym celem artykułu jest przeanalizowanie $\mathrm{w}$ świetle zasad analizy systemowej twierdzenia, zgodnie z którym innowacyjność technologiczna realizuje funkcję bezpieczeństwa społeczeństwa w czasie kryzysu. Poddanym analizie zjawiskiem spełniającym warunki kryzysu jest pandemia COVID-19 w Polsce jako potencjalne zagrożenie dla realizacji funkcji bezpieczeństwa państwa. W oparciu o naczelny cel artykułu można zbudować hipotezę badawczą o następującym brzmieniu, poddaną dalej procesowi weryfikacji: „Innowacje technologiczne mają pozytywne znaczenie dla bezpieczeństwa społecznego i państwowego w czasie kryzysu zdrowotnego". Hipoteza ta zostanie poddana weryfikacji w świetle metody systemowej, odpowiadającej przedmiotowi badania, tj. systemowi państwowemu, globalnemu systemowi bezpieczeństwa.

\section{Konceptualizacja kluczowych pojęć, uzasadnienie metody badawczej}

Dla usystematyzowania wywodu konceptualizacyjne ramy obejmą wykorzystywane w artykule kategorie i pojęcia, tj. „innowacja”, „bezpieczeństwo", "kryzys", „system polityczny”. Operacjonalizacja pozwoli zminimalizować znaczeniowe nieścisłości i wykluczy ryzyko zaciemniającej wieloznaczności terminologicznej. Zostaną również przedstawione zasady metody systemowej i katalogu odpowiadające metodzie zagadnień.

Wprowadzenie pojęcia „innowacji” przypisuje się Josephowi Schumpeterowi, choć samą zasadę wynalazczości sformułował francuski socjolog, Gabriel Tarde, którego pisma J. Schumpeter mógł znać (Musiał, 
Chrzanowski 2018; zob. również Sikora, Uziębło 2013). W ujęciu Schumpeteriańskim warunki innowacyjności obejmują:

- nowy produkt,

- lepsze metody produkcji,

- otwarcie rynku na produkt,

- nowe źródła półfabrykatów lub surowców,

- przeobrażenie danej gałęzi gospodarki po wpływem nowego produktu (Musiał, Chrzanowski 2018: 42-45).

Zdefiniowana $w$ ten sposób zasada innowacyjności stała się impulsem przemian cywilizacyjnych w Europie od XIX w., za których katalizator uznaje się wynalazek usprawnienia silnika parowego w 1869 r. przez Jamesa Watta (Trevelyan 1980: 409; Trevelyan 1982: 446-460) (proces usprawniania metod produkcji rozpoczął się znacznie wcześniej i 1869 r. uznaje się za umowną cezurę). Konsekwencje procesualnych przemian w obszarze metod i środków produkcji dotknęły każdego aspektu bytu człowieka (komunikacja, handel, transport i inne), stąd okres ten określa się mianem rewolucji przemysłowej; w największym stopniu wpłynął na jakościowe i ilościowe przemodelowanie zasad wytwórczości i rozwój prywatnych środków własności i wolnej konkurencji.

W naukach ekonomicznych innowacyjność uznaje się za "kombinację czynników produkcji przeprowadzoną w nowy sposób" (Musiał, Chrzanowski 2018: 44), "twórcze burzenie”, więc - według J. Schumpetera - wpływa na nieustanne przeobrażenia struktury produkcji i użytkowania. Kierunek przeobrażeń spełnia funkcję „liberalizacji”, tj. ułatwiania i upraszczania funkcjonowania człowieka w świecie. Jest ona realizowana ze szczególnym powodzeniem od pierwszej i drugiej fali rewolucji przemysłowej, dalej zaś stanowiąca przyczynę i konsekwencję rewolucji cyfrowej. Warte uwagi jest ujęcie Kennetha Galbraitha, który pojęcie innowacji łączy ze zwiększaniem poczucia bezpieczeństwa w skali społecznej (Musiał, Chrzanowski 2018: 49). Ekscentryczne lub dziwaczne pomysły zasługują na nazwę wynalazków, lecz nie przekroczą granicy komercjalizacji z uwagi na znikomy potencjał masowego wykorzystania (koszt, wąski zakres użyteczności itp.).

Pojęcie bezpieczeństwa przysparza wielu problemów definicyjnych; uznaje się je za polisemantyczne, o wysokiej dynamice znaczeniowej, należy ono również do katalogu problemów centralnych wielu dyscyplin jako kategoria fundamentalna. Znaczenie leksykalne dotyczy stanu pozbawionego zagrożeń powiązanego z poczuciem pewności (Stańczyk 1996: 15). 
Kategoria cechuje się więc ujęciem negatywnym, przyjmuje się jednak, że wymiar pozytywny obejmujący nie tylko poziom przetrwania w związku ze społecznymi potrzebami człowieka należy w taki sam sposób do zakresu znaczeniowego. Filozoficzne wniknięcie w pojęcie bezpieczeństwa ujawnia dyskusyjność osiągnięcia stanu pewności przetrwania wobec mnogości czynników definiowanych jako realnie lub potencjalnie niebezpieczne. Analiza terminu potwierdza procesualność pojęcia bezpieczeństwa, wykluczając rozwiązania określające je jako stan. Bezpieczeństwo stanowi powiązanie czynnika eliminacji zagrożeń, stabilizacji warunków przetrwania ze stanem zapewniającym możliwość rozwoju rozumianego jako wprowadzanie udogodnień, ułatwień i uproszczeń życia codziennego. Stąd za immanentną cechę analizowanej kategorii uznaje się również czynnik rozwoju pozwalający nie tylko na fizyczne przetrwanie, lecz także na względną swobodę poprawy jakości bytowej.

W literaturze przedmiotu zwraca się uwagę na dynamikę znaczeniowego pola kategorii. Pojęcie bezpieczeństwa przez wieki silnie utożsamiane z potencjałem militarnym współcześnie wobec znacznego przyrostu czynników wpływających na pozycję podmiotów, poszerzyło zakres przedmiotowy. O ile kategorie bezpieczeństwa podmiotowego obejmują nadal cztery grupy (jednostkowe - personalne, indywidualne; grupowe - rodzinne, klanowe; narodowe - państwowe, krajowe; globalne - regionalne, międzynarodowe), o tyle katalog bezpieczeństwa przedmiotowego stanowi zasób rozwijający się - energetyka, demografia, cyberprzestrzeń, informacja, polityka historyczna, wprowadziwszy na stałe pojęcia soft i smart obok hard power $\mathrm{w}$ stosunkach międzynarodowych. Architekturę bezpieczeństwa charakteryzuje powszechna dziś cecha usieciowienia i trudniejszych do wskazania granic, co dobrze ilustruje dylemat definicyjny bezpieczeństwa państwa, kraju i narodu. Gdzie bowiem przebiega granica medialnego systemu państwa wobec rzeczywistości globalnej wymiany danych?

System polityczny stanowi podsystem systemu społecznego, w ramach którego cechy - wzajemnej zależności części i granic - decydują o wyodrębnieniu od otoczenia, tj. od innych systemów. Klasyczne ujęcie Eastonowskie system orientuje na pojęcie suwerenności (Beyme 2005: 181; Bertalanffy 1984), u Karla Deutscha cechami systemu są: spójność i kowariancja, uzupełniane o czynnik przemian (niedotykający tożsamości) ukierunkowany na maksymalizację przetrwania. Strukturę systemu politycznego cechuje wielowymiarowość i usieciowienie, można jednocześnie wskazać system tzw. wejść i wyjść. Siłę systemu politycznego potwierdza 
realizowanie kluczowego celu, tj. przetrwania i rozwoju, wymagające przewagi postawy konsensualnej nad konfliktową w procesie agregacji interesów i utrzymania równowagi. Konsens w systemie jest procesem opartym na ciągłym uzgadnianiu oddziałujących na siebie preferencji w kierunku osiągnięcia efektywności; poziom rywalizacji i konsensu w wypadku społeczeństw aktywnych nie tyle sobie odpowiada, co wykazuje przewagę woli konsensu.

W świetle koncepcji systemu politycznego za kluczowe uznaje się stabilność oraz zdolności systemu do regeneracji i innowacyjności w odpowiedzi na czynniki zewnętrzne i wewnętrzne. Im system bardziej skomplikowany, tym trudniej zachować wysoki poziom obu parametrów. Za główne wyzwania systemów przyjmuje się zachowanie dynamiki rozwoju wraz z realizacją planowych zmian i modyfikacji wynikających z niezależnych okoliczności lub też ingerencji aktywnego czynnika obywatelskiego/ partycypantów.

Ontologia systemu politycznego odpowiada zasadom i regułom wszelkich systemów, od systemu zarządzania przedsiębiorstwem po system bezpieczeństwa globalnego, w centrum sytuując kategorię stabilności i zdolności adaptacyjne struktury systemu do okoliczności zewnętrznych i wewnętrznych uwarunkowań (agregacja interesów). Stąd też analiza systemowa wykazuje szerokie możliwości badawcze w odniesieniu do wielu płaszczyzn (systemy polityczne, systemy ekonomiczne itd.).

Słownikowe znaczenie pojęcia kryzysu brzmi następująco: „sytuacja, w której jakiś konflikt staje się tak poważny, że grozi wybuchem wojny, zmianą rządu lub innym radykalnym rozwiązaniem” (SJP: „kryzys”); kryzysem jest: „okres załamania, przesilenia i potencjalnego przełomu w funkcjonowaniu danego systemu społecznego lub politycznego” (SJP: „kryzys"), doprecyzowanie zaś zależne jest od sektora dotkniętego dysfunkcją, np. kryzys parlamentarny, rządowy, gospodarczy.

Przyczyny kryzysu w ujęciu systemowym oznaczać mogą: 1) brak uwzględnienia zagrożenia czynników destabilizujących, które można było antycypować (funkcja prognostyczna $\mathrm{w}$ ramach np. nauki o stosunkach międzynarodowych) (Sennet 2010: 2) obecność czynnika nieprzewidzianego, o niskim stopniu prawdopodobieństwa wystąpienia. Czynnik kryzysowy może mieć charakter subiektywny lub obiektywny; obiektywny wpływa na destabilizację większej ilości powiązanych systemów, subiektywny wykazuje słabości struktury pojedynczych podsystemów, w których bez względu na wpływ czynników zewnętrznych realizacja funkcji 
stabilizacyjno-rozwojowej została zakłócona. Kryzys o zasięgu globalnym, stanowiący konsekwencję emisji wirusa SARS-CoV-2, zgodnie z klasyfikacją obejmuje podsystemy systemu globalnego (systemy państwowe, regionalne systemy współpracy) i system globalny.

Krajowe i ponadnarodowe systemy bezpieczeństwa zdrowotnego wykazały zmienną skuteczność walki i przeciwdziałania, można jednak wskazać pewne kierunki i tendencje na obu płaszczyznach. W przeważającym stopniu $\mathrm{w}$ państwach przyjmowano taktykę promocji środków ochrony sanitarnej i redukcji bezpośrednich kontaktów międzyludzkich do niezbędnego minimum, zarówno w sferze zawodowej, jaki i prywatnej. Nastąpiła w związku z tym intensyfikacja przeniesienia aktywności pracy, rozrywki, kontaktów - w cyberprzestrzeń, wpływając na poziom stabilizacji emisji wirusa, odciążenie służby zdrowia i zmniejszanie zapotrzebowania na artykuły sanitarne. Zachowując ciągłość funkcjonowania pewnych sektorów z większym niż dotychczas wykorzystaniem cyberprzestrzeni, nie uniknięto jednak poważnego załamania innych, co dotyczy zwłaszcza gastronomii, turystyki, kultury.

Można więc uznać, że w ramach systemów krajowych i systemu globalnego szeroko wykorzystuje się możliwości technologiczne w celu zminimalizowania strat i szkód $\mathrm{w}$ ramach powiązanej struktury systemów krajowych (Jak Polacy korzystaja z Internetu i telefonu w czasie pandemii 2020).

\section{Specyfika współczesnych innowacji - nowe technologie}

Termin „innowacyjność” znajduje powszechne zastosowanie w odniesieniu do narzędzi usprawniających funkcjonowanie jednostek i społeczeństw w realiach obostrzeń pandemicznych. Przyjmijmy więc, że przeanalizowane zostaną wytwory w ten sposób określane w systemie wymiany informacji, tj. raportach, analizach i wynikach konkursu dotyczących okresu pandemii poddanego podsumowaniom, tj. okresu wiosenno-letniego 2020 i jesienno-zimowego 2020. W ramach przeglądu pod uwagę zostanie wzięte najważniejsze krajowe i światowe zestawienie dotyczące innowacyjności lub też innowacyjności w zastosowaniu do walki z konsekwencjami COVID-19.

Dystans społeczny i separowanie wybranych grup społecznych stanowiły niezmienny element państwowych strategii walki z pandemią 
w okresie jesienno-zimowym (AOTMiT 2020) i nadal są kluczowowym elementem redukcji transmisji wirusa. Przyjęte kierunki na poziomach państwowych determinowały poszukiwanie rozwiązań zapewniających przede wszystkim bezpieczeństwo pracy, wymiany gospodarczej, rozrywki i codziennych koniecznych aktywności (zakupy, opieka medyczna).

W raporcie Polskiej Agencji Rozwoju Przemysłu (Monitoring trendów innowacyjności - Raport 8 2020) analiza dotyczy pierwszej połowy 2020 r. Prace badanych podmiotów państwowych obejmują sektor cyfryzacji, nauk medycznych, wsparcia start-upów i małych przedsiębiorstw. Do światowych liderów innowacyjności należą w Niemcy (detronizując Koreę Południową), liderem cyfryzacji zaś nadal pozostaje Finlandia. Innowacyjność sprzężona jest prymarnie z wykorzystywanymi narzędziami technologicznymi, na bazie których projektuje się usprawnienia obejmujące wymienione dziedziny.

We wrześniu 2020 r. Europejski Instytut Innowacji i Technologii nagrodził 207 innowacyjnych projektów i przedsiębiorstw z 32 krajów. Obejmują one rozwiązania „z zakresu biotechnologii i diagnostyki, wykorzystania prototypów 3D do ponownej konfiguracji zatłoczonych części miasta i współdzielonych obszarów roboczych, usuwania zakłóceń w łańcuchach dostaw żywności, a także rozwiązania zmniejszające zanieczyszczenie powietrza" (EIT 2020). W raporcie wyszczególniono obszary innowacyjności i charakter projektów, wśród których wszystkie bazują na rozwoju technologicznym oraz cyfrowych narzędziach (EIT Community Innovation 2020). Warunki innowacyjności w rozumieniu klasycznych definicji spełniają projekty medyczne, których celem jest odkrycie instrumentów medycznych, wpływających na znaczne zmiany w obszarze bezpieczeństwa sanitarnego lub diagnostyki czy leczenia.

W ramach cyklicznie prowadzonego konkursu PARP w 2020 r. wyróżniono innowacje z obszarów technologii medycznej (nagrodzone: inteligentny stetoskop, proteza ucha o działaniu bakteriobójczym, fotowoltaika, produkt stymulujący odporność roślin) (To oni tworza przyszłość 2020). Prace nad zgłoszonymi propozycjami - jak można wnosić - nie zostały zdeterminowane okolicznościami pandemicznymi, lecz stanowią realizację trendu, zgodnie z którym technologia wspiera lub stanowi obszar realizacji nowych idei. 
Globalny indeks innowacyjności jest przygotowany rokrocznie od 2007 r., biorąc pod uwagę dane ze 131 krajów i podsumowując wiodące tendencje i kierunki. W raporcie Global Innovation Index podkreśla się wciąż obecny potencjał innowacyjności związany z nowymi technologiami (,virtual reality is the key to it") (Dutta, Lanvin, Wunsch-Vincent 2020), a obejmujący obszar badań farmaceutycznych, medycznych, usprawnienia dotyczące transportu, mobilności i „czystej energii”. Za lidera innowacyjności w raporcie GII2020 uznano Szwajcarię. W dokumencie tym uwzględniono okoliczności pandemiczne, wpływające na przeorientowanie uwagi podmiotów na sieć cyberprzestrzenną i znaczny spadek wymiany ekonomicznej. W latach 2018-2019 najintensywniejsze inwestycje objęły teleinformatykę i high-tech. Pandemia wpłynęła - wedle analiz autorów raportów - na koncentrację wokół innowacji dotykających obszary edukacji, zdalnej pracy i handlu.

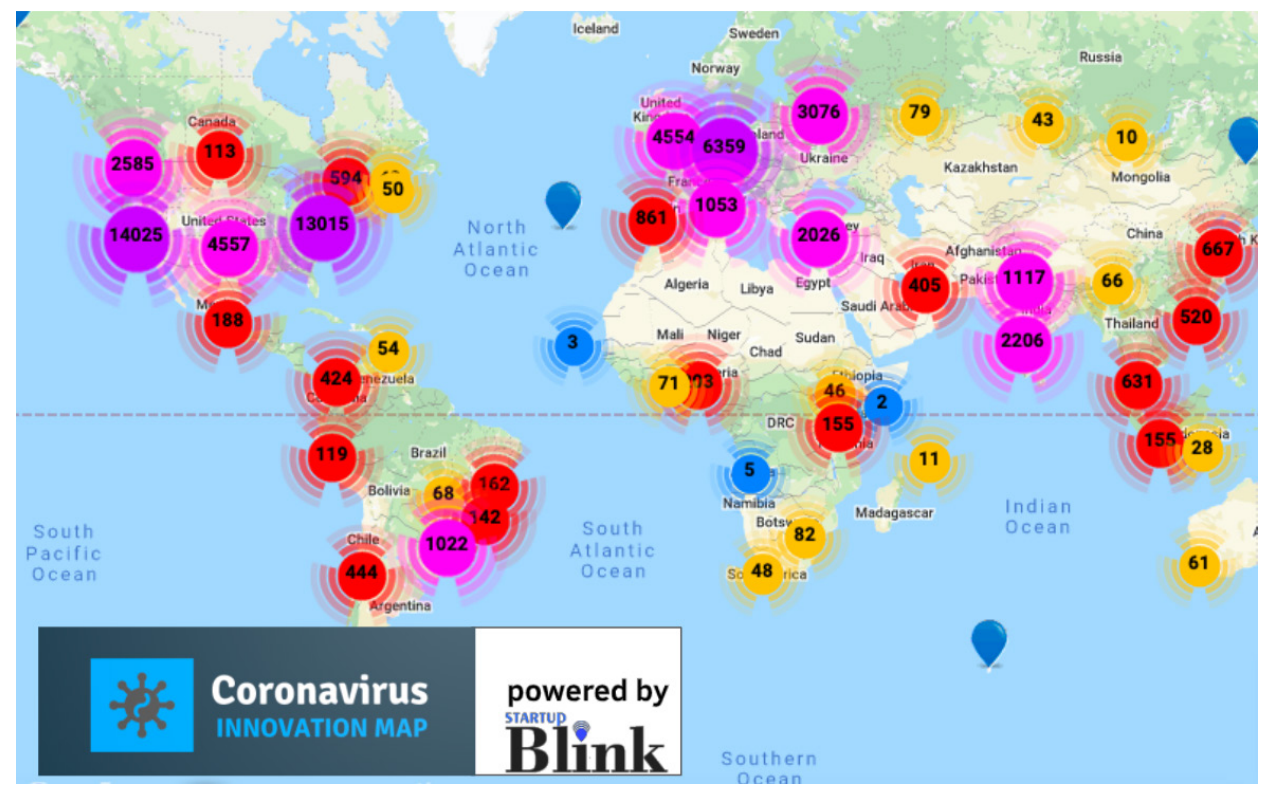

Ilustracja 1. Mapa innowacji w porządku krajowym (2021)

Firma StartUpBlink we współpracy z podmiotami lokalnymi uruchomiła platformę, w której zestawiane są dane dotyczące innowacji związanych z pandemią. Uzupełniane na bieżąco, stanowią dobry przewodnik dla specjalistów i każdego zainteresowanego. Dane uporządkowane są 
w zestawienia krajów i miast. Liderem wśród państw są Stany Zjednoczone, dalej Izrael i Kanada (Belgia, Szwajcaria, Kanada, Wielka Brytania, Singapur, Hiszpania, Południowa Korea, Luksemburg; zob. ilustracja 1). W zestawieniu miast w czołówce znajdują się: San Francisco, Nowy York, Moskwa (Boston, Toronto, Tel Aviv, Los Angeles, Seul, Taipei, San Diego). W dniu 2 kwietnia 2021 r. w zestawieniach zarejestrowano 1078 innowacji. Obejmują one kategorie, takie jak prewencja, diagnostyka, handel, edukacja, w przeważającej mierze wykorzystując zaawansowane technologie.

Kierunek wykorzystania narzędzi technologicznych potwierdza raport World Economic Forum („Digital tools and strategies have become crucial in this effort") (World Economic Forum 2020a). W raporcie uwzględniono ponad $150 \mathrm{mln}$ angielskojęzycznych źródeł publikacyjnych. Przedstawiono dane z 41 krajów, przybliżono charakter 232 wdrożonych innowacji. Dane uporządkowano w ramach siedmiu kategorii obejmujących: środowisko informacyjne (promowanie wiedzy, narzędzi wymiany danych), wykrywanie i rozprzestrzenianie się wirusa, opiekę zdrowotną, usprawnienie procesów leczenia, odporność gospodarczą, spójność społeczną i cyberbezpieczeństwo. Jak zaznaczono w dokumencie, rozwiązania mogą odpowiadać więcej niż jednej kategorii (World Economic Forum 2020a: 4).

Konkludujac, innowacje czasu pandemii według zestawień obejmują przede wszystkim takie obszary jak wymiana handlowa, usługi finansowe, bezpieczeństwo sanitarne, oraz aktywności dotyczące sfery komunikacji społecznej, rozrywki i kultury. Dominującym trendem jest wykorzystywanie technologii cyfrowych jako narzędzia antykryzysowego.

Dotychczasowa cyfryzacja umożliwiła płynną kontynuację aktywności systemu wewnątrzpaństwowego, poszerzając strefy pracy zdalnej przez kontakt sieciowy, stymulując wymianę ekonomiczną i badania medyczne. Trudno jednak stwierdzić, by charakter usprawnień odpowiadał klasycznym definicjom innowacyjności. Bardziej adekwatnym określeniem jest tzw. ultra fast innovation, stanowiący efekt twórczego wykorzystania technologicznych możliwości. W nowszych ujęciach innowacyjność oznacza "pomyślną ekonomicznie eksploatację nowych pomysłów” (Matusiak 2011: 111), co pozwala na szersze wykorzystanie pojęcia. W tym zaś zakresie ciągle istnieją szerokie możliwości, na co wskazują analizy i konkluzje branżowych raportów. Obszar e-medycyny, e-commerce, e-administracji, badań diagnostycznych nadal się rozwija w kierunku nadanym przez obostrzenia pandemiczne, dotykającym sfery kontaktów bezpośrednich, eliminowanych w świetle zaleceń strategii państwowych. W ramach 
istotnych trendów gospodarczych obserwuje się intensyfikację sieciowych modeli sprzedaży, sieciowego marketingu i kontaktu z odbiorcą treści dotychczasowo bezpośrednich (teatr, koncerty), poszerzenia narzędzi kontaktów społecznych przez platformy (edukacja, wideokonferencje, sport), reorientację branż (samochodowa, paliwowa) na rynek medyczny (respiratory, płyny odkażające).

\section{Innowacyjność technologiczna - szanse i zagrożenia. Konkluzja}

W czasach obecnej wyraźnej rywalizacji podmiotów państwowych z niepaństwowymi zasady konkurencji o realizację własnych wartości i interesów wymagają spojrzenia łączącego potrzeby bieżące z perspektywą długofalową. Technologiczna innowacyjność odpowiada warunkom reżimów sanitarnych, pozwalając na zachowanie ciągłości działania podmiotów państwowych i gospodarczych. W obszarze bezpieczeństwa sanitarnego nowe rozwiązania powstałe na bazie technologii pozwalają na zapewnienie systemowi sprawności, efektywności, realizując zasadę stabilności i dynamizmu.

Można więc przyjąć, że istnieją podstawy empiryczne do przyjęcia hipotezy badawczej, tj. że innowacje technologiczne w okresie kryzysu sanitarnego wpływają pozytywnie na utrzymanie systemowych funkcji bezpieczeństwa. Przeprowadzona analiza wskazuje jednak na potencjalne obszary ryzyka związane z przyjętym modelem bezpieczeństwa. W wielu obszarach zapewne dojdzie do utrzymania wypracowanych w okresie pandemii rozwiązań. Dotyczą one z wielką dozą prawdopodobieństwa obszarów aktywności zawodowej i funkcjonowania wielu sektorów państwa. Należy więc zauważyć, że skoncentrowanie wysiłków na cyfryzacji w ramach infrastruktury krytycznej państwa, gospodarki, komunikacji i kultury wskazuje na potencjalne niebezpieczeństwo w sytuacji zagrożenia funkcjonowania cyfrowego środowiska systemu państwowego, opartego na internetowej sieci wymiany i przechowywania danych. W obszarach strategicznych istotne jest $\mathrm{w}$ związku z tym sprzężenie poziomu ucyfrowienia z możliwością kontynuacji działań w wypadku kryzysu lub zagrożenia systemów cyfrowych cyberprzestrzeni. 


\section{Bibliografia}

AOTMiT (2020), Przeglad strategii COVID-19 w okresie jesienno-zimowym, opracowanie analityczne, https://www.aotm.gov.pl/media/2020/08/1_1_aotmit_strategi_walki_z_covid-19_v.1.0.pdf (30.03.2021).

Bertalanffy, L. von (1984), Ogólna teoria systemów: podstawy, rozwój, zastosowania, (Warszawa: Państwowe Wydawnictwo Naukowe).

Beyme, K. von (2005), Wspótczesne teorie polityczne (Warszawa: Wydawnictwo Naukowe Scholar).

Ciesielski, M. (2020), Innowacje w kryzysie, https://www.obserwatorfinansowy.pl/ tematyka/makroekonomia/trendy-gospodarcze/innowacje-w-kryzysie/ (8.02.2021).

Dutta, S., B. Lanvin, S. Wunsch-Vincent (red.) (2020), Global Innovation Index. Who Will Finance Innovations?, (Ithaca: Cornell University), https:/ / www.wipo.int/ edocs/pubdocs/en/wipo_pub_gii_2020.pdf (6.02.2021).

EIT Community Innovation Tackling the COVID-19 Crisis, https:/ / eit.europa.eu/sites/ default/files/eit_community_eit_cri_innovations.pdf (30.03.2021).

EIT, (2020), 207 przełomowych innowacji i przedsięwzięć nagrodzonych łaczna kwota 60 milionów euro w ramach inicjatywy reagowania kryzysowego EIT (EIT Crisis Response Initiative), 8 września, https://eit.europa.eu/sites/default/files/pl-pr _eit_cri_sept_2020.pdf (30.03.2021).

Coronawirus Innovation Map, https:/ / coronavirus.startupblink.com/ (2.04.2021).

Kryzys, [w:] Encyklopedia PWN, https://encyklopedia.pwn.pl/haslo/kryzys; 4011371.html (6.02.2021).

Kryzys, [w:] Słownik Jezyka Polskiego PWN, https://sjp.pwn.pl/slowniki/kryzys.html (6.02.2021).

Innowacje [Innovation] (2011), [w:] K.B. Matusiak (red.), Innowacje i transfer technologii. Stownikpojęć,(Warszawa):111, https:/ / www.parp.gov.pl/files/74/81/469/12812. pdf (29.03.2021).

Jak Polacy korzystaja z Internetu i telefonu w czasie pandemii. Raport Krajowego Rejestru Długów, https://krd.pl/getattachment/3d366a9c-020e-4610-a401-87fce5 7283 bd (30.03.2021).

Mapa innowacji w porządku krajowym, https://www.startupblink.com/blog/coronavirus-innovation-map/ (2.04.2021).

Nieć, M., J. Łapiński, J. Orłowska, R. Zakrzewski, P. Chaber (2020), Monitoring trendów innowacyjności, Raport 8, https:/ / www.parp.gov.pl/component/publications/publication/monitoring-trendow-w-innowacyjnosci-raport-8 (30.03.2021).

Musiał G., I. Ch. Chrzanowski (2018), Schumpeter - Lange - Galbraith. Innowacje w teorii i praktyce, "Studia Ekonomiczne. Zeszyty Naukowe Uniwersytetu Ekonomicznego w Katowicach", 362: 40-58. 
Sennet, R. (2010), Etyka dobrej roboty (Warszawa: Warszawskie Wydawnictwo Muza). Stańczyk, J. (1996), Wspótczesne pojmowanie bezpieczeństwa, (Warszawa: Instytut Studiów Politycznych PAN).

Sikora, J., A. Uziębło (2013), Innowacja w przedsiębiorstwie - próba zdefiniowania, „Zarządzanie i Finanse", 2(2): 351-376.

To oni tworza przyszłość. Polskie innowacje nagrodzone w konkursie PARP i NCBR (2020), https://www.parp.gov.pl/component/content/article/58682:to-oni-tworza-przyszlosc-polskie-innowacje-nagrodzone-w-konkursie-parp-i-ncbr (30.03.2021).

Trevelyan, G.M (1980), English Social History (London: Penguin Books).

Trevelyan, G.M. (1982), A Shortened History of England (London: Penguin).

World Economic Forum (2020a), Critical Frontier. Leveraging Technology to Combat COVID-19 „White Paper", July, https://www.weforum.org/whitepapers/ critical-frontier-leveraging-technology-to-combat-covid-19 (2.04.2021).

World Economic Forum (2020b), ICT COVID-19 Response: Partnering with Technology Companies to Combat COVID-19, http://www3.weforum.org/docs/WEF_ Tech_4_COVID_Early_Compendium_2020.pdf (5.04.2021). 